\title{
ISOLASI ENZIM LIPASE DARI ENDOSPERMA KELAPA SEBAGAI BAHAN REFERENSI PETUNJUK PRAKTIKUM BIOKIMIA
}

\author{
Khatmizarullah $^{1^{*}}$, Lalu Rudyat Telly Savalas ${ }^{2}$, Yunita Arian Sani Anwar ${ }^{3}$ \\ ${ }^{2}$ Program Studi Pendidikan Kimia, Universitas Mataram. Jalan Majapahit No. 62 \\ Mataram, NTB 83112, Indonesia. \\ * Coressponding Author. E-mail: izankhan17@gmail.com
}

Received: 16 Maret 2021

\author{
Accepted: 30 November 2021 Published: 30 November 2021 \\ doi: 10.29303/cep.v4i3.2563
}

\begin{abstract}
Abstrak
Penelitian ini bertujuan untuk mengetahui hal-hal sebagai berikut: 1) Prosedur isolasi enzim lipase dari endosperma kelapa; dan 2) Tingkat keandalan dan penerapan deskripsi Panduan Laboratorium Biokimia tentang prosedur ini. Penelitian ini menggunakan desain penelitian 4D dan merupakan proyek penelitian dan pengembangan (mendefinisikan, merancang, mengembangkan, dan menyebarluaskan). Seluruh mahasiswa program studi pendidikan kimia tahun ajaran 2019-2020 yang telah mendaftar mata kuliah Biokimia I merupakan populasi penelitian ini, sedangkan sampel sebanyak 20 mahasiswa dipilih secara acak. Hasil penelitian menunjukkan bahwa nilai indeks Aiken (V) validitas (kelayakan) dari empat validator adalah 0,73 , yang menunjukkan bahwa panduan laboratorium yang dihasilkan valid dan praktis untuk digunakan. Tanggapan dari mahasiswa dan dosen digunakan untuk mengukur kepraktisan panduan laboratorium. Pemeriksaan jawaban mahasiswa dan dosen menunjukkan bahwa panduan laboratorium yang disiapkan termasuk dalam kategori sangat layak dari segi kepraktisan. Temuan ini mendukung kesimpulan bahwa panduan laboratorium Biokimia I yang dihasilkan untuk mengisolasi enzim lipase dari endosperma kelapa dapat dipraktikkan dan sangat berguna untuk digunakan dalam proses pengajaran.
\end{abstract}

Kata Kunci: Enzim Lipase, Pengembangan, Panduan Laboratorium.

\section{Isolation of Lipase Enzyme from Coconut Endosperm as Reference Material for Biochemistry Laboratory Guide}

\begin{abstract}
The objectives of this study are to ascertain the following: 1) The procedure for isolating the lipase enzyme from coconut endosperm; and 2) The degree of reliability and applicability of the Biochemistry Laboratory Guide's description of this procedure. This study uses a $4 D$ research design and is a research and development project (define, design, develop, and disseminate). All students enrolled in the chemistry education study program for the 2019-2020 academic year who have registered for the Biochemistry I course make up the population of this study, while the sample of 20 students was chosen at random. The findings showed that the Aiken index (V) value for validity (feasibility) out of four validators was 0.73 , indicating that the laboratory guide generated is valid and practicable to use. Responses from students and lecturers are used to gauge the laboratory guide's practicality. The examination of student and lecturer replies revealed that the prepared laboratory guide falls within the extremely feasible category in terms of practicality. These findings support the conclusion that the Biochemistry I laboratory guide produced for isolating lipase enzymes from coconut endosperm is practicable and extremely useful for use in the teaching process.
\end{abstract}

Keywords: Lipase Enzymes, Development, Laboratory Guide. 


\section{Chemistry Education Practice, 4 (3), 2021 - 295}

Khatmizarullah, Savalas, Anwar

\section{PENDAHULUAN}

Lemahnya proses pembelajaran yang berujung pada rendahnya kualitas pendidikan menjadi salah satu persoalan yang dihadapi pendidikan Indonesia saat ini. Siswa kurang terdorong untuk mengasah kemampuan berpikir kritisnya, jika diperhatikan. Siswa cerdas dalam teori tetapi kurang dalam praktik karena pembelajaran difokuskan pada menghafal dan menyimpan informasi. (Ariyati, 2010). Oleh karena itu, untuk mengatasi hal ini diperlukan motivasi positif untuk mengembangkan pengetahuannya sendiri serta bertanggung jawab terhadap hasil belajaranya (Gasong, 2009). Cara pandang semacan ini dalam dunia pendidikan semakin populer dan dipahami sebagai pandangan konstruktivisme.

Dalam teori pembelajaran modern, peserta didik diarahkan menjalani serangkaian kegiatan yang didisain untuk dapat membangun pengetahuannya sendiri, menemukan cara bagaimana suatu teori sains ditemukan dan merumuskan ilmu dengan kata-katanya sendiri. Paham konstruktivisme ini dipandang baik karena dapat meningkatkan retensi pengetahuan peserta didik (Febriana, 2021; Awang, 2017). One of the benefits of good learning and in line with the nature of PLD is that from the concepts he learns, he develops the fundamental abilities to conduct experiments, the capacity to solve problems using a scientific method, and increases understanding of the subject. He also develops the fundamental abilities to make observations and to communicate the results of those observations both orally and in writing. It can also facilitate the reconstruction of concepts or the building of concepts, allowing the lecturer to play a role in strengthening and (Murti et al, 2014).

Di perguruan tinggi, praktikum dapat dianggap sebagai komponen mata kuliah. Di perguruan tinggi, praktikum biokimia adalah salah satu pilihan yang tersedia. Program studi pendidikan kimia FKIP Universitas Mataram memasukkan biokimia sebagai salah satu disiplin ilmunya. Seperti diajarkan di banyak perguruan tinggi dan juga disarankan Divisi Biokimia Himpunan Kimia Indonesia, kuliah Biokimia diberikan dalam dua semester, di mana penekanan pada semester pertama lebih fokus pada struktur dan fungsi biomakromolekul. Biokimia I merupakan mata kuliah yang mempelajari tentang asam amino, peptida dan protein, DNA, RNA dan biosintesis protein, enzim, kinetika michelis menten, inhibisi enzim, isolasi, pemurnian dan karakterisasi enzim, Hormon, virus, regulasi enzim dan integrasi topik Biokimia. Dalam pembelajarannya mata kuliah Biokimia Idilakukan di dalam kelas untuk mempelajari teori serta konsep dan dilaboratorium untuk menemukan fakta dari teori dan konsep yang dipelajari. Secara alamiah, Ketika mahasiswa terlibat dalam percobaan di laboratorium mereka akan mempelajari lebih banyak hal. Ini dapat dipahami karena Ketika akan melaksanakan praktikum, mahasiswa diharuskan mempelajari modul percobaan yang akan dilaksanakan, mempelajari teori yang melandasinya, mengikuti tes awal sebelum praktikum dan sebagainya, hingga akhirnya setelah pelaksanaan praktikum mahasiswa dapat mengkonstruksi pengetahuannya sendiri dari hasil percobaan (Emda, 2017). Jadi, berbeda dengan pembelajaran di kelas yang lebih banyak berisi teori dan kurang melibatkan aspek motorik peserta didik, pekerjaan di laboratorium mempunyai karakteristik yang berbeda karena keterampilan psikomotorik akan terbangun Ketika mahasiswa bekerja dengan prosedur, peralatan, kerja kolektif bersama sesama mahasiswa maupun dengan asisten lab (Atrisman dkk, 2017).

Praktikum akan berjalan dengan baik jika panduan praktikum digunakan sebagai pedoman dalam melaksanakan praktikum Asmaningrum, dkk. (2018). Meskipun demikian, petunjuk praktikum seyogyanya juga dapat memicu atau mengarahkan peserta untuk mengembangkan nalar dan daya piker kritis, sehingga tidak semata-mata berfungsi seperti cook-book dan yang tidak dapat memungkinkan peserta mengaktualisasi keterampilannya sendiri (Putri, 2021). meliputi tema praktikum, objective atau tujuan praktikum, pengantar atau pendahuluan yang berisi latar belakang serta teori dasar, daftar material dan peralatan yang dibutuhkan. Sebagai pandual bagi peserta, lembar observasi juga sering diikutsertakan sebagai panduan bagi peserta dalam menentukan data apa yang akan diambil. Selain itu, seringkali terdapat sejumlah pertanyaan terkait yang berfungsi baik sebagai pemandu dalam pembentukan alur praktikum yang logis, maupun sebagai bahan evaluasi ketercapaian tujuan praktikum. (Darmayanti, dkk., 2020). Dengan demikian, panduan 


\section{Chemistry Education Practice, 4 (3), 2021 - 296}

Khatmizarullah, Savalas, Anwar

praktikum yang seringkali disusun ulang, diperbaiki, direvisi berkali-kali berdasarkan evaluasi yang melibatkan peserta sehingga fungsinya menjadi lebih optimal dari waktu ke waktu (Prayitno, 2017).

Mata kuliah Biokimia I materi yang dipraktikumkan adalah identifikasi asam amino dan protein, aktivitas enzim protease pada nanas, isolasi kasein, ektraksi DNA tumbuhan, serta SDS-PAGE. Saat ini pada kegiatan praktikum Biokimia I belum ada petunjuk praktikum isolasi enzim. Sebagian besar enzim merupakan protein sehingga sifat-sifat yang dimiliki protein juga berlaku bagi enzim. Dalam ranah fisiologi, enzim merupakan biokatalis yang mengkatalisis hampir semua reaksi penting dalam organisme hidup. Dari tinjauan kinetika reaksi, enzim mempercepat berlangsungnya suatu reaksi, namun dari sisi kesetimbangan, enzim tidak merubah posisi kesetimbangan reaksi. Sifat khas lain dari enzim adalah spesifisitasnya terhadap substrat tertentu (Champe dalam Sya'bani, 2017). Dalam skema pemurnian enzim yang kompleks, berbagai Teknik isolasi perlu dilakukan, misalnya dari pemilihan sumber enzim, preparasi atau produksi enzim skala besar, pemisahan awal enzim dari pengotornya, misalnya melalui pengendapan menggunakan ammonium sulfat dan sentrifugasi, dialisis, hingga pemurnian lebih lanjut menggunakan satu atau beberapa jenis kromatografo kolom (Brockerhoff dan Jensen dalam Djarkasi dkk, 2017).

Beberapa jenis enzim yang meluas penggunaannya dan juga telah banyak dieksplorasi karakteristik biokimianya adalah amilase, lipase, dam protease. Kelompok enzim tersebut juga memiliki nilai ekonomis tinggi yang secara umum berperan memecah senyawa biopolimer kompleks menjadi senyawa sederhana (Supryiatna dkk, 2015). Enzim lipase sendiri berperan memecah ikatan ester antara asam lemak dengan gliserol pada trigliserida. Karena substrat alaminya yang bersifat hidrofobik, enzim lipase bekerja pada antar muka (interface) minyak-air (Djarkasi dkk, 2017. Selain berfungsi sebagai enzim penghidrolisis, dalam lingkungan nir-air, lipase juga dapat mengarahkan terjadinya reaksi trans-esterifikasi, suatu reaksi yang penting dalam pembuatan biodiesel (Gunawan, 2020). Biji-bijian yang banyak mengandung lemak merupakan sumber penting bagi lipase, terutama pada fase perkecambahan biji. Saat biji berkecambah, terjadi proses imbibisi atau masukkan air ke dalam biji-bijian yang selanjutnya mengaktifkan enzim-enzim hidrolitik seperti protase, amilase dan lipase. Pengaktifan enzim tersebut esensial untuk memobilisasi cadangan makanan di dalam biji-bijian untuk digunakan sebagai sumber karbon bagi pertunasan hingga perkembagan lebih lanjut dari tumbuhan berbiji (Sya'bani, 2017). Jenis enzim yang dominan juga bergantung pada bentuk penyimpanan cadangan makanan dominan yang ada pada biji, misalnya biji Bunga matahari atau kelapa yang banyak mengandung lemak akan memiliki aktivitas lipase yang tinggi. Sebaliknya, umbi kentang atau singkong akan memiliki enzim penghidrolisis karbohidrat kompleks (Arifan dkk, 2011). Buah atau biji-bijian yang sering digunakan untuk isolasi enzim lipase adalah buah kelapa. Keberadaan enzim hydrolase juga bervarsiasi pada tanaman pengasilnya. Sebagai gambaran, semua bagian kelapa dalam fase germinasi atau sekitar 30 hari sejak imbibisi (tunas. Kentos, daging buah dan tunas muda) diketahui memiliki aktivitas lipase. Aktivitas enzim lipase pada kelapa tertinggi pada bagian daging buah kelapa yakni sebesar 258,996 unit/mL (Su'i, 2011)

Agar proses isolasi lebih lancar bagi mahasiswa dalam mengisolasi enzim lipase dari endosperma kelapa, maka diperlukan panduan praktikum yang bersifat teori dan prosedur. Enzim lipase harus diisolasi dari endosperma kelapa, namun tidak ada petunjuk praktis untuk melakukannya. Akibatnya, manual praktis yang dapat digunakan sebagai referensi harus dikembangkan.

\section{METODE}

Penelitian ini merupakan contoh penelitian pengembangan (Research and Development). Instruksi praktis Biokimia I tentang isolasi enzim lipase merupakan modul praktikum tentang enzim yang belum pernah digunakan sebelumnya, meskipun prosedurnya sederhana dan bahan-bahannya relatif mudah didapatkan. Prosedur pembuatan modul dalam penelitian ini adalah model 4D, yang memiliki empat tahap, -mendefinisikan, mendesain, mengembangkan, dan menyebarluaskan-, adalah desain penelitian yang digunakan. Hanya sampai tahap pengembangan yang dicakup dalam penelitian ini karena keterbatasan waktu dan kesulitan untuk melakukan diseminasi.

Harapan yang ingin dicapai dari penelitian ini adalah dihasilkannya modul yang shahi dan praktis. Studi dilakukan terhadap seluruh mahasiswa pendidikan kimia semester 6 yang telah memprogram mata kuliah Biokimia I 
di salah satu perguruan tinggi negeri di Nusa Tenggara Barat, dengan peserta penelitian sebanyak 20 responden mahasiswa semeseter 6

Data didapatkan dengan menyebar kuisioner terhadap peserta mata kuliah terkait sehingga didapatkan umpan balik yang shahih. Selain itu, pendapat ahli juga berperan dalam menilai validitas modul. Hasil yang diperoleh dianalisis dengan Aiken's V.

\section{HASIL DAN PEMBAHASAN}

Pengembangan petunjuk praktikum isolasi enzim lipase dari endosperma kelapa dikembangkan dengan model pengembangan 4D (Thiagarajan, 1974). Adapun hasil dan pembahasan dari masing-masing tahap dapat diuraikan sebagai berikut:

\section{Tahap Define (Pendefinisan)}

Tahap define merupakan tahap awal dari penyelidikan ini. Analisis awal-akhir dan analisis material dilakukan pada titik ini. Informasi dari hasil analisis berupa berbagai makalah dari literature review, RPS, dan RTM. Dari analisis ini diharapkan dapat digunakan pengetahuan tentang bahan kajian dan indikator pencapaian yang menjadi pedoman praktikum. Semester akan terdiri dari 3 sks, dengan 2 sks untuk instruksi tatap muka dan 1 sks untuk praktikum di laboratorium.

Analisis artikel mengenai isolasi enzim lipase dari endosperma kelapa bertujuan untuk mengetahui proses isolasi enzim lipase dari endosperma kelapa. Studi dari beberapa literatur dijadikan dasar untuk mendisain skema kerja yand dijadikan sebagai referensi untuk melaksanakan praktikum isolasi enzim lipase dari endosperma kelapa. Endosperma kelapa yang digunakan dalam penelitian ini teridiri dari endosperma kelapa yang belum bertunas dan endosperma kelapa yang sudah bertunas. Dari praktikum yang dilakukan didapatkan masingmasing 6 tabung conical crude lipase. Crude lipase yang diperoleh selanjutnya kemudian dilakukan beberapa uji yakni uji aktivitas lipase, penentuan kadar protein, penentuan berat molekul, serta penentuan kinetika enzim. Uji aktivitas lipase dilakukan dengan melakukan reaksi hirdolisis VCO dengan enzim lipase, dan produk asam lemak yang dihasilkan ditentukan dengan titrasi. Berdasarkan percobaan yang dilakukan diperloeh aktivitas lipase dari endosperma kelapa yang belum bertunas sebesar 0,4 unit $/ \mathrm{mL}$, sedangkan aktivitas lipase dari ensoperma kelapa yang sudah bertunas sebesar
0.2 unit $/ \mathrm{mL}$. Penentuan kadar protein dilakukan dengan menggunakan metode biuret. Dimana dalam percobaan ini standar protein yang digunakan adalah kasein. Sebelum diukur serapan pada gelombang tertentu ditentukan panjang gelombang maksimal denganmembuat kurva serapan pada rentang $450 \mathrm{~nm}$ hingga 800 nm.Dari kurva serapan diperoleh panjang gelombang maksimal sebesar 554 nm.Berdasarkan pengukuran dan perhitungan diperoleh hasil kadar protein yang terdapat dalam sampel enzim lipase dari endosperma kelapa yang belum bertunas sebesar $1.637,5 \mathrm{mcg} / \mathrm{mL}$ dan $1.354,5 \mathrm{mcg} / \mathrm{mL}$ untuk enzim lipase dari endosperma kelapa yang sudah bertunas. Percobaan penentuan kadar protein ini peneliti melakukan modifikasi langkah kerja, dimana sebelumnya menggunakan alat spektrofotometer UV-Vis Specord 200 Plus dalam menentukan panjang gelombang maksimal diganti dengan menggunakan aplikasi berbasis android yakni photometrix V1.1.16. Aplikasi photometrix V1.1.16 yang digunakan pada penelitian ini didownload melalui playstore. Cara kerja dari aplikasi ini adalah memberikan nilai RGB berdasarkan tingkat warna dari suatu larutan. Berdasarkan perocabaan yang dilakukan diperloleh kadar protein yang terdapat dalam enzim lipase dengan cara ini sebesar 2.162,99 $\mathrm{mcg} / \mathrm{mL}$ untuk enzim lipase dari endosperma kelapa yang belum bertunas, dan 1.796,02 $\mathrm{mcg} / \mathrm{mL}$ untuk enzim lipase dari endosperma kelapa yang sudah bertunas. Hasil yang diperoleh dengan menggunakan aplikasi photometrix V1.1.16 tidak jauh berbeda dengan menggunakanan alat spektrofotometer UV-Vis Specord 200 Plus sehingga dalam percobaan penentuan kadar protein dengan metode biuret ini dapat memanfaatkan aplikasi photomterix V1.1.16 sebagai alternatif apabila tidak ada alat spektrofotometer UV-Vis Specord 200 Plus.

Penentuan berat molekul protein ditentukan dengan menggunakan SDS-PAGE. Metode SDS-PAGE adalah pemisahan protein didasarkan pada perbedaan berat molekul protein dalam suatu medan listrik. Berdasarkan percobaan yang dilakukan diperoleh gel hasil elektroforesis seperti gambar berikut: 


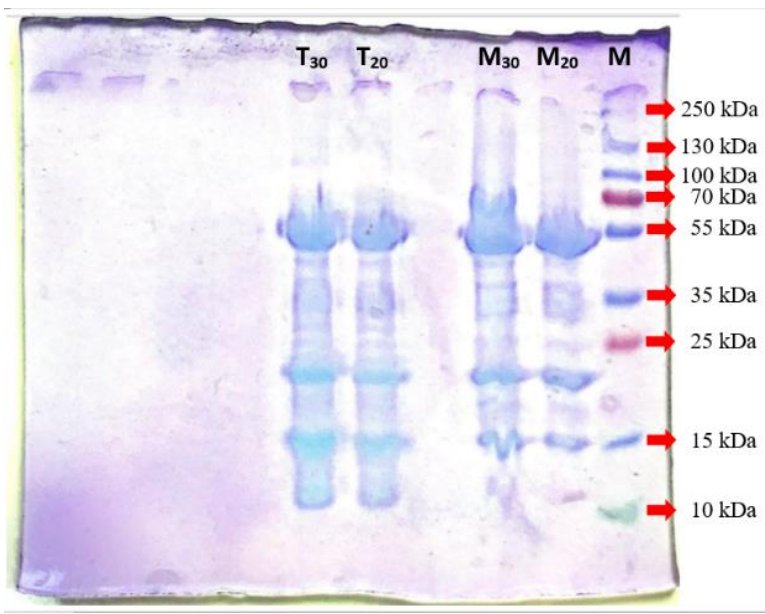

Gambar 1. Gel hasil elektroforesis marker dan sampel

Keterangan Gambar:

- M : Marker Protein

- $\quad \mathrm{M}_{20}$ : Sampel Enzim Lipase dari endosperma kelapa yang belum bertunas (Volume $20 \mu \mathrm{L}$ )

- $\quad \mathrm{M}_{30}$ : Sampel Enzim Lipase dari endosperma kelapa yang belum bertunas (Volume $30 \mu \mathrm{L}$ )

- $\quad \mathrm{T}_{20}$ : Sampel Enzim Lipase dari endosperma kelapa yang sudah bertunas (Volume 20 $\mu \mathrm{L})$

- $\quad \mathrm{T}_{30}$ : Sampel Enzim Lipase dari endosperma kelapa yang sudah bertunas (Volume 20 $\mu \mathrm{L})$

Berdasarkan perhitungan dengan rumus Rf diperoleh sampel enzim lipase dari endosperma kelapa yang belum bertunas terdiri dari 3 pita dengan berat molekul berturut turut yakni $66 \mathrm{kDa}, 22 \mathrm{kDa}$, dan $14 \mathrm{kDa}$. Sedangkan sampel enzim lipase dari kelapa yang sudah bertunas terdiri dari 3 pita dengan berat molekul masing-masing pita yakni $63 \mathrm{kDa}, 21 \mathrm{kDa}$, dan $13 \mathrm{kDa}$. Sedangkan untuk penentuan kinetika enzim ditentukan dengan metode titrasi. Adapun substrat yang digunakan pada percobaan ini adalah minyak VCO (Virgin Coconut Oil). Substrat tersebut dibuat dalam bentuk emulsi minyak. Emulsi minyak tersebut yang akan dihidrolisis oleh enzim lipase. Adapun laju reaksi awal (Vo) dari rekasi hidrolisis enzim lipase pada substrat minyak VCO dapat dilihat pada tabel berikut:
Tabel 1. Nilai laju awal (Vo) minyak VCO

\begin{tabular}{cc}
\hline $\begin{array}{c}\text { Konsentrasi Substrat } \\
\text { (ppm) }\end{array}$ & Vo (mmol/menit) \\
\hline 16500 & 0,00099 \\
24800 & 0,00117 \\
33000 & 0,00145 \\
41300 & 0,00163 \\
49600 & 0,00172 \\
57800 & 0,0019 \\
66100 & 0,00226 \\
74900 & 0,00244 \\
82600 & 0,00244 \\
90900 & 0,00244 \\
\hline
\end{tabular}

Berdasarkan tabel di atas, diperoleh kurva hubungan antara konsentrasi substrat dan laju awal yang dapat dilihat pada Gambar 2.

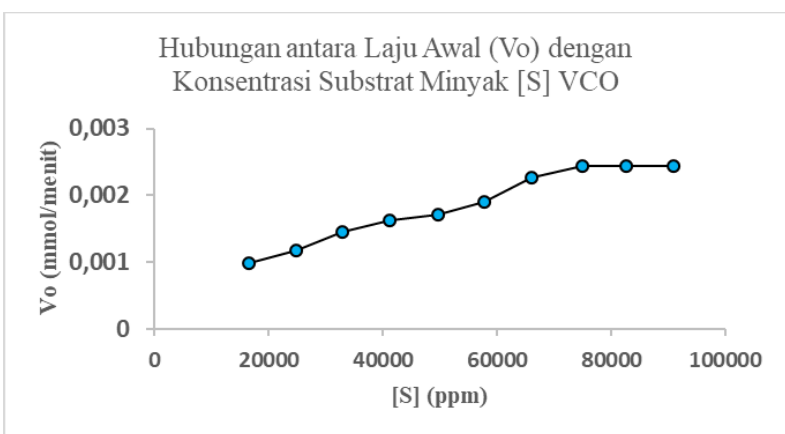

Gambar 2. Plot Michaelis-Menten

Berdasarkan tabel 1, terlihat bahwa laju reaksi awal pada reaksi hidrolisis yang terjadi dengan enzim lipase dari endosperma kelapa sebagai katalistor terus meningkat seiring dengan bertambahnya nilai konsentrasi substrat. Akan tetapi laju reaksi menjadi tidak bertambah lagi pada konsentrasi 82.600 ppm. Pada titik kosentrasi tersebut laju reaksi selanjutnya tidak bertambah meskipun konsentrasi dan substrat terus ditambah, hal ini menunjukkan bahwa telah tercapainya laju reaksi maksimum ( $\mathrm{V}_{\text {maks }}$ ) pada reaksi katalitik tersebut. Nilai $\mathrm{V}_{\text {maks }}$ dapat ditentukan berdasarkan pada Kurva LineweaverBurk (Gambar 3). 


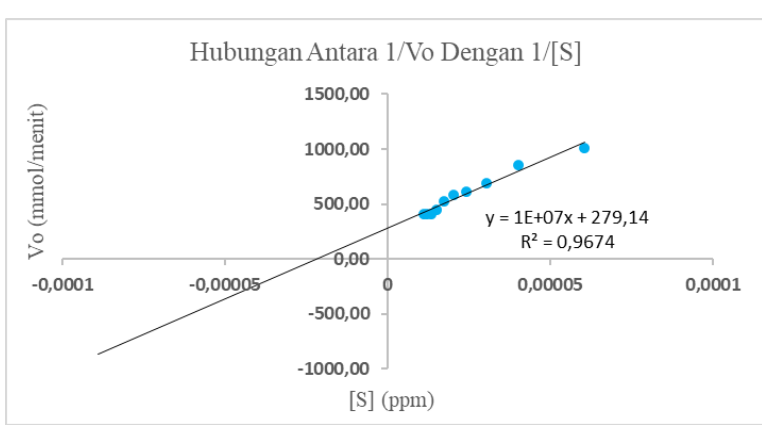

Gambar 3. Kurva Lineweaver-Burk

Berdasarkan kurva Lineweaver-Burk, diperoleh persamaan regresi linear yang dapat digunakan untuk menentukan nilai $\mathrm{V}_{\text {maks }}$ dan nilai Km. Berdasarkan hasil perhitungan diperoleh nilai $\mathrm{V}_{\text {maks }}$ sebesar $3,58 \times 10^{-3} \mathrm{mmol} / \mathrm{menit}$ dan

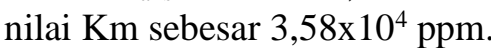

Berdasarkan hasil analisis, petunjuk praktikum yang dikembangkan dapat digunakan dalam mengisolasi enzim lipase dari endosperma kelapa. Adapun materi yang disampaikan kepada mahasiswa tergolong lengkap dan komprehensif, baik itu yang meliputi aspek teoritis maupun prosedural. Adapun materi teoritis yang dipaparkan berkaitan dengan pengertian enzim, teknik isolasi enzim, faktor-faktor yang mempengaruhi aktivitas enzim, karakeristik enzim lipase, metode penentuan kadar protein suatu enzim, SDS-PAGE, dan kinetika enzim. Materi prosedural, diberikan pemaparan dalam bentuk skema kerja mengenai cara mengisolasi enzim lipase dari endosperma kelapa, cara menentukan aktivitas enzim lipase dari endosperma kelapa dengan metode titrasi, penentuan kadar protein enzim lipase dengan metode biuret, penentuan berat molekul dengan SDS-PAGE, dan penentuan kinetika enzim dengan metode titrasi.

\section{Tahap Design (Perancangan)}

Penemuan dan identifikasi tahap define digunakan untuk mengatur tahap desain, yang merupakan tingkat lanjutan. Pada tahap ini dilakukan penyusunan petunjuk praktikum yang dimulai dari perancangan sampul dan dilanjutkan dengan penyusunan komponen-komponen proses praktikum yang meliputi judul praktikum, tujuannya, landasan teori dasar, alat dan bahan, prosedur kerja, observasi, analisis data, evaluasi, dan referensi. Prototipe 1 dibuat menggunakan hasil desain ini sebagai petunjuk praktis.

\section{Tahap Develop (Pengembangan)}

Tahap develop merupakan tahap yang digunakan untuk mengetahui apakah perangkat yang dikembangkan pada tahap sebelumnya telah berhasil mendapatkan hasil yang diharapkan dalam arti keshahihan dan kedapaterapannya. Produl awal dari tahap design berupa purwarupa 1 dilakukan uji validitas untuk mendapatkan masukan atau saran dari validator ahli untuk memperbaiki produk yang telah dikembangkan menjadi. Seperangkan instrument standar telah digunakan untuk menggali pendapat ahli untuk menilai modul yang dikembangkan. Komponen ini terdiri atas tampilan visual grafis, presentasi, kelayakan isi serta penggunaan bahasa yang layak. Instrumen yang baik harus memenuhi dua kriteria utama yakni bersifat valid dan realibilitas.

Dengan cara kerja seperti ini, tidak semua proses berjalan dengan mulus, dalam arti masukan dan catatan dari ahli digunakan sebagai pertimbangan dan masukan untuk penyempurnaan modul, di antaranya perlu diperhatikan sinkronisasi antara content dengan RPS MK Biokima, memperbaiki kata-kata dan penulisan yang telah ditandai oleh validator pada draft petujuk praktikum, dan penggunaan warna kuning sebagai background, diganti dengan warna lain yang tidak mengaburkan tulisan di dalamnya.

Indeks Aiken's digunakan untuk menilai kelayakan petunjuk praktikum yang dikembangkan. Dari analisis ini dijumpai keempat validator bersepakat memberi penilaian shahih terhadap petunjuk praktikum. Dari tahap ini diperoleh hasil berupa purwarupa 2. Karena puwarupa ini merupakan hasil elaborasi dari masukan ahli, selanjutnya dihasilkan purwarupa 2 yang siap diujicobakan secara terbatas pada peserta kuliah Biokimia I maupun pada dosen dari berbagai universitas.

Uji coba terbatas dilakukan terhadap 20 orang mahasiswa program studi pendidikan kimia dan 3 dosen yang berasal dari universitas Mataram dan universitas Brawijaya. Pada tahap ini uji coba dilaksanakan untuk memperoleh respon mahasiswa dan dosen terhadap petunjuk praktikum yang telah dikembangkan. Angkat respon mahasiswa dan dosen terdiri atas beberapa pernyataan meliputi sepuluh, tujuh, dua dan dua pertanyaan untuk komponen kemenarikan, kemudahan penggunaan petunjuk praktikum, durasi dan manfaat modul, berurutan. Secara umum, baik mahasiswa maupun dosen memberika persepsi baik terhadap petunjuk praktikum tersebut. Hasil validasi di atas diikhtisarkan pada Gambar 4. 


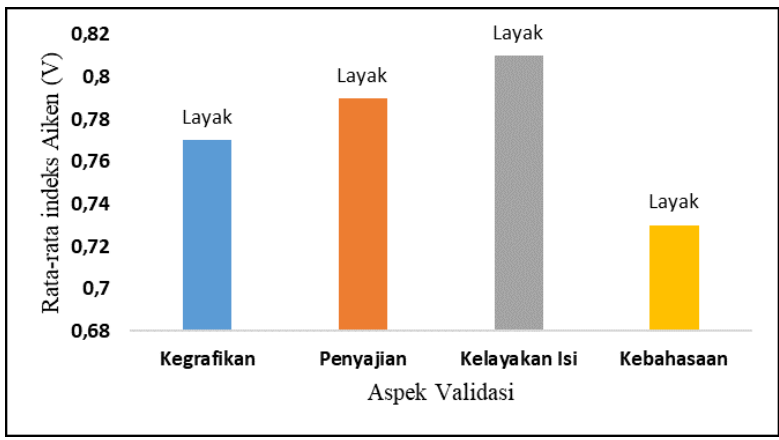

Gambar 4. Respon atas kelayakan modul

Penemuan dan identifikasi tahap define digunakan untuk mengatur tahap desain, yang merupakan tingkat lanjutan. Pada tahap ini dilakukan penyusunan petunjuk praktikum yang dimulai dari perancangan sampul dan dilanjutkan dengan penyusunan komponen-komponen proses praktikum yang meliputi judul praktikum, tujuannya, landasan teori dasar, alat dan bahan, prosedur kerja, observasi, analisis data, evaluasi, dan referensi. Prototipe 1 dibuat menggunakan hasil desain ini sebagai petunjuk praktis.

Berdasarkan grafik respon mahasiswa terhadap petunjuk praktikum yang dikembangkan berdasarkan indeks praktikalitas diperoleh presentase praktikalitas sebagaimana pada Tabel 2.

Berdasarkan informasi tersebut di atas, diketahui bahwa rata-rata kepraktisan petunjuk praktikum yang dibuat untuk digunakan dalam proses pembelajaran adalah $86,4 \%$ dengan kategori sangat praktis. Hasil jawaban dosen yang tergambar pada Gambar 6 mendukung hal tersebut.

Berdasarkan grafik respon dosen terhadap petunjuk praktikum dikembangkan berdasarkan indeks praktikalitas diperoleh presentase praktikalitas berturut-turut yaitu $76 \%$, $96 \%$, dan 96\% dengan kategori berturut-turut yakni praktis, sangat praktis dan sangat praktis. Dengan rentang praktikalitas antara $80 \%$ hingga $100 \%$, atau rata-rata $89,3 \%$, petunjuk praktikum yang telah disusun dapat dikatakan memenuhi kriteria kepraktisan.
Tabel 2. Hasil respon mahasiswa terhadap petunjuk praktikum Biokimia

\begin{tabular}{|c|c|c|}
\hline Responden & Persentase Praktikalitas (\%) & Kategori \\
\hline R1 & 98 & Sangat Praktis \\
\hline R2 & 75 & Praktis \\
\hline R3 & 88 & Sangat Praktis \\
\hline R4 & 96 & Sangat Praktis \\
\hline R5 & 70 & Praktis \\
\hline R6 & 81 & Sangat Praktis \\
\hline R7 & 77 & Praktis \\
\hline R8 & 71 & Praktis \\
\hline R9 & 93 & Sangat Praktis \\
\hline R10 & 93 & Sangat Praktis \\
\hline R11 & 100 & Sangat Praktis \\
\hline R12 & 94 & Sangat Praktis \\
\hline R13 & 93 & Sangat Praktis \\
\hline R14 & 94 & Sangat Praktis \\
\hline R15 & 88 & Sangat Praktis \\
\hline R16 & 82 & Sangat Praktis \\
\hline R17 & 80 & Sangat Praktis \\
\hline R18 & 90 & Sangat Praktis \\
\hline R19 & 86 & Sangat Praktis \\
\hline R20 & 79 & Praktis \\
\hline
\end{tabular}

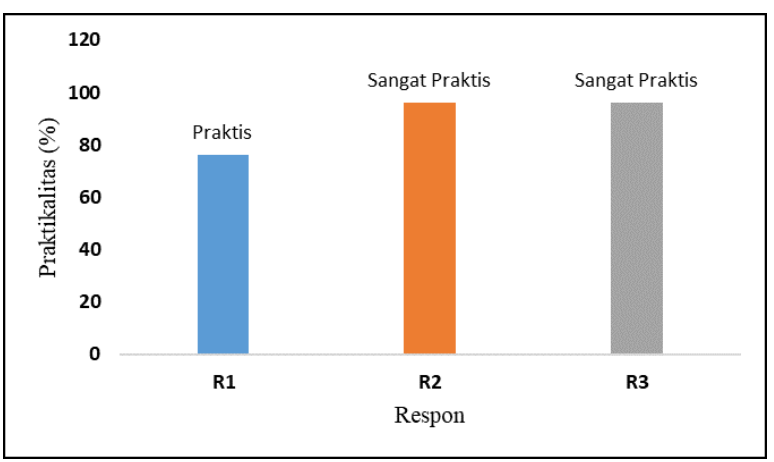

Gambar 6. Grafik kepraktisan petunjuk praktikum Biokimia I

\section{SIMPULAN}

Dari studi ini dapat disimpulkan bahwa Isolasi enzim lipase dari endosperma kelapa terdiri dari beberapa langkah yakni; (1) ekstraksi endosperma kelapa dengan menggunakan larutan buffer phospat $\mathrm{pH}$ 7,5 (dalam keadaan dingin) (2) Sentrifugasi ekstrak endosperma kelapa pada kecepatan $7000 \mathrm{rpm}$ (3) pemisahan fraksi skim (yang mengandung enzim lipase) dari fraksi krim (yang mengandung minyak). Tingkat kelayakan dan kepraktisan petunjuk praktikum yang telah dikembangkan telah terpenuhi sehingga dapat dapat digunakan dalam proses pembelajaran. 


\section{Chemistry Education Practice, 4 (3), 2021 - 300}

Khatmizarullah, Savalas, Anwar

\section{DAFTAR PUSTAKA}

Arifan, F., Yulianto, M.E., Wikanta, D.K., \&Damayanti, N. (2011). Pengembangan BioreaktorEnzimatik Untuk Produksi Asam Lemak dariHasil Samping Penggilingan Padi Secara InSitu. Semarang: Jurusan Teknik Kimia PSD IIIUNDIP.

Ariyanti. (2010). Pembelajaran berbasis Praktikum Untuk meningkatkan Kemampuan Berpikir Kritis Mahasiswa. Jurnal Matematika dan IPA. 1(2), 1-12.

Asmaningrum, Henie, P., Imam, K., \& Kamariah. (2018). Pengembangan Panduan Praktikum Kimia Dasar Terintegrasi Etnokimia Untuk Mahasiswa. Jurnal Tadris Kimiya. 3(5), 125-134.

Atrisman., Hairida., \& Fitriani. (2017). Analisis Kemampuan Psikomotorik Dalam Praktikum Biokimia Percoban Lipid pada Mahasiswa Program Studi Pendidikan Kimia Universitas Muhammadiyah Pontianak. Ar-Razi Jurnal Ilmiah. 4(1), 1-12.

Awang, I.S. (2017). Strategi Pembelajaran, Tinjauan Umum Bagi Pendidik. Kalimantan Barat: STKIP Presda Khatulistiwa.

Darmayanti, N. W. S., Wijaya, I. W. B., \& Sanjayanti, N. P. A. H. (2020). Kepraktisan Panduan Praktikum Ipa Sederhana Sekolah Dasar (SD) Berorientasikan Lingkungan Sekitar. ORBITA: Jurnal Kajian, Inovasi dan Aplikasi Pendidikan Fisika,6(2), 310-314.

Djarkasi, G.S., Sri, R., \& Zuheid, N. (2017). Isolasi dan Aktivitas Spesifik Enzim Lipase Indigenous Biji Kenari. Jurnal Teknologi Pertanian. 8(1), 28-35.

Emda, A. (2017). Laboratorium sebagai sarana pembelajaran kimia dalam meningkatkan pengetahuan dan ketrampilan kerja ilmiah. Lantanida journal, 5(1), 83-92.

Febriana, R. (2021). Kompetensi guru. Bumi Aksara.

Gasong, D. (2009). Model pembelajaran konstruktivistik sebagai alternative mengatasi masalah pembelajaran. Penelitian (tidak diterbitkan). PPs Teknologi Pendidikan, UNJ Jakarta.

Gunawan, E.R., Suhendra, D., Rohana, R. and Komalasari D. (2020). Methyl linoleate synthesis from cottonoil seeds: An optimation study, Acta Chimica Asiana 3(2), 163-169.

Murti, S., Muhibbuddin, \& Nurmaliah, C. (2014).

Penerapan Pembelajaran Berbasis

Pratikum Untuk Meningkatkan

Kemampuan Kognitif dan Psikomotorik Pada Perkuliahan Anatomi Tumbuhan. Jurnal Biologi Edukasi. 6(1), 1-8.

Prayitno, T.A. (2017). Pengembangan Petunjuk Praktikum Mikrobiologi Program Studi Pendidikan Biologi. Jurnal Biota. 3(1), 31-37.

Putri, A.N, (2021). The Development of an Inquiry-based Laboratory Manual for Student of Biology Education, Journal of Educational Research and Evaluation, 5(1), 105-111.

Su'i., Harijono., Yunianta., \& Auliani'am. (2011). Perubahan Aktivitas Enzim Lipase Dari Buah Kelapa Selama Pertunasan. Berk. Penel. Hayati. 16(155159).

Supriyatna, A., Dea,A., Ayu, A.J., \&Dyna, H. (2015). Akitivitas Enzim Amilase, Lipase, dan Protease dari Larva. Jurnal Istek. 9(2), 18-32.

Sya'bani', N., Winni, A., \& Djihan, R.P. (2017). Isolasi dan Karakterisasi Lipase Dari Kecambah Biji Alpukat (Presea americana Mill). Jurnal Atomik. 2(2), 209-212.

Thiagarajan, S., Semmel, D. S., \& Semmel, M. I. (1974). Intructional Development for Teachers of Expectional Children Training a Source Book. Blomington: Central for Innovation on Teaching the Handicapped, Minneapolis, Indiana University. 